Мирослав Топић

Петар Ж. Буњак*

Универзитет у Београду, Филолошки факултет

\title{
О СЈЕНКЈЕВИЧЕВОМ СВЕТИОНИЧАРУ, ЈОШ ЈЕДНОМ
}

Рад је посвећен новели Хенрика Сјенкјевича Светионичар (Latarnik). Уз осврт на текст и преглед главних позиција из досадашње литературе, старије и новије, аутори износе нека своја запажања.

Кључне речи: Хенрик Сјенкјевич, Светионичар (Latarnik), генеза, карактерологија, Адам Мицкјевич, Пан Тадеуи (Pan Tadeusz), „текст у тексту“.

Текст о овој теми аутори су замислили пре безмало четврт века, али их је потоња плодна коауторска сарадња одвела у сасвим другом, за обојицу испрва неочекиваном смеру. Првопотписани аутор Мирослав Топић (1937-2012), био је, поред свега осталог, пасионирани истраживач Адама Мицкјевича и надасве његовог средишњег дела, спева Пан Тадеуш (Pan Tadeusz, 1834). У својим предавањима на београдској полонистици М. Топић се сваке треће године враћао двосеместралном курсу посвећеном рецепцији Пана Тадеуша у пољској књижевности и култури, те је тако студентима саопштавао како „општепознате“, тако и резултате властитих истраживања и запажања. У том контексту посебно се заустављао на бисеру пољске новелистике XIX века новели Светионичар (Latarnik, 1881) Хенрика Сјенкјевича. Пошто су „у етар“ отишле читаве прегршти података, али без чујног одјека, другопотписани аутор одлучио је да за ову, њему веома важну прилику, сачини свод сазнања из првобитно замишљеног рада, али да притом не заобиђе ни новију литературу о Сјенкјевичевој новели.

\section{1.}

Сјенкјевичев Светионичар, који је завршен 1880, а први пут публикован крајем 1881. године у варшавском часопису Њива (Niwa), био је једна од најранијих манифестација потребе поколења позитивиста (реалиста) за поновним вредновањем наслеђа пољског романтизма. То није био само омаж једноме од највећих

p.bunjak@fil.bg.ac.rs 
поетских и идеолошких ауторитета минуле епохе, већ и успостављање нове, позитивистичке вредносне хијерархије романтичарске књижевности, а задуго и књижевноисторијског канона.

Будући да Светионичар, премда превођен на српски више пута, ${ }^{1}$ не спада у најпознатија дела овога писца у нашој средини, задржаћемо се најпре на самој новели, њеној једноставној структури и, како ће се испоставити, вишеслојној проблематици.

Радња новеле крајње је сведена, минималистичка, рекло би се чак - оскудна: стари пољски емигрант, који се целог живота потуца од немила до недрага, срећним стицајем околности добија посао светионичара у Панами, на улазу у луку Аспинвол; неко време води миран живот рутински обављајући своје дужности - све док му не стигне пакет књига, међу којима и Мицкјевичев Пан Тадеуш; толико урања у лектиру овога спева да заборавља да упали фар на светионику и губи службу, настављајући тако своје судбинско потуцање...

Недостатна радња компензује се, међутим, пребогатим реминисценцијама и читавим слаповима унутрашњег емотивног живота главног од свега тројице јунака. Друга двојица су амерички конзул у Панами Ајзак Фалконбриџ, који запошљава светионичара, и радник лучке капетаније Џонс који светионичару довози намирнице, а на концу саопштава о губитку посла и одвози га с острва.

Фалконбриџ је „технички“ јунак - служи као актер експозиције, а његова одлука као замајац читавог приповедања. Проблем изненадног нестанка, свакако смрти у олуји, претходног светионичара морао се решити у року од дванаест сати, а то је било у надлежности конзула-резидента САД-а у Панами. Конзулов проблем био је велики и „лако је разумети његову радост кад се потпуно изненада већ истога дана јавила замена“" (Sienkiewicz 1964: 357). ${ }^{2}$ Наратор затим даје сведен физички опис: човек већ стар, од седамдесет и више година, али крепак, прав, војничког држања, плавоок, потпуно беле косе и препланулог лица, „потиштеног и тужног, али честитог“ (Sienkiewicz 1964: 357). Фалконбриџ започиње уобичајени разговор о послу током којег кандидат за светионичара излаже своју биографију и пружа одговарајуће доказе, међу којима и документ о учешћу у америчком грађанском рату. Конзул узима документ и чита: „Хм! Скавињски? То је ваше пре-

1 Појављивала се под насловима: „Стражар на морској кули“ (1885), „Палилац на фару“ (1905), „Чувар светиље“ (1914), „Палилац на кули светиљи“ (1921) итд. Детаљније у: Буњак 1999.

2 Превод цитираних одломака из овог и других извора - П. Б. 
зиме?...“ (Sienkiewicz 1964: 358). Тако је читаоцу, током тривијалне бирократске идентификације, први пут саопштено презиме главног јунака, којим га, узгред, наратор потом једино и именује - сасвим изостаје податак о његовом крштеном имену. ${ }^{3}$ На необично богати и разноврсни curriculum vitae Скавињског вратићемо се у наредном одељку.

На конзулово запажање да је „престар“ за светионичара главни јунак се „отвара“ и моли:

- Sir - прозбори изненада кандидат узбуђеним гласом. - Веома сам посустао и изнурен. Много сам тога, видите, претурио. Ово је једно од оних места за којима сам највише жудео да их добијем. Стар сам, потребан ми је мир! Потребно ми је да кажем себи: овде ћеш одсад да седиш, ово је твоја лука. Ax, Sir! То зависи само од вас. Други пут ми се оваква прилика за посао можда неће указати. Каква срећа што сам се затекао у Панами... Преклињем вас... Тако ми Бога, ја сам као брод који ће, не уђе ли у луку, потонути... (Sienkiewicz 1964: 358)

И, одлазећи са сцене, конзул је преломио: Скавињски је добио толико жељени посао. Од тог тренутка прича се испреда готово искључиво око унутрашњег света главног јунака, његових психолошких стања и реминисценција, пласирајући постепено, кроз присећања, мноштво података о његовом животу и прикљученијима.

Оставивши свог јунака на балкону испод самих фарова готово читаву ноћ, приповедач се саглашава: „Био је доиста као брод којем је олуја ломила јарболе, кидала ужад, једра, који је бацала од облака до дна мора, у који је ударала таласима, пљувала пеном - а који је ипак скренуо у луку“" (Sienkiewicz 1964: 359). Без обзира на сва посртања и неуспехе, Скавињски је био оптимиста, а ево како наратор оцртава временски лук његовог живота:

...увек је био пун вере и није губио наду да ће све још изићи на добро. Зими би увек живнуо и предсказивао некакве велике догађаје. Чекао их је нестрпљиво и од саме мисли на њих преживљавао читава лета... Али зиме су пролазиле једна за другом и Скавињски је дочекао само то да су му избелеле главу. Напослетку је остарио - почео да губи енергију. Његово стрпљење све је више почињало да личи на резигнацију. Некадашња смиреност претворила се у склоност према ганућу, те је овај прекаљени војник стао да се претвара у плачљивка, спремног да засузи из најмањег разлога. Сем тога, с времена на време, тресла би

3 Понегде се, нарочито у електронским ресурсима, може срести његово име као Јузеф (Józef), али то нема упоришта у Сјенкјевичевом тексту. 
га најстрашнија носталгија, коју би могла подстаћи свака околност: призор ластавица, сивих птица налик на врапце, снег на планинама или каква мелодија попут неке коју је некад чуо... (Sienkiewicz 1964: 361)

Други део новеле посвећен је светионичаревој свакодневици. Усамљенички живот на кули-светиљи, на острвцу усред мора, и свакодневна рутина доводили су га, с временом све више, до неке дотад му непознате равнотеже, осећаја потпуног стапања с небом и морем. Морепловци верују да их узбуркано море у ноћи дозива по имену, а Скавињски иде даље: „Ако морски бескрај може тако да дозива, онда човека, кад остари, дозива могућно и други бескрај, још тамнији и тајанственији, а што је уморнији од живота, то су му дража та дозивања.“ А затим следи и непосредан закључак да „старост воли осаму као да предосећа гроб“, те да је „светионик за Скавињскога већ био такав полугроб“ (Sienkiewicz 1964: 363). И затим:

Све са чиме се сусреће светионичар огромно је и лишено чврстих, одређених облика. Небо је једна општост, вода друга, а између тих бесконачности налази се усамљена људска душа! То је живот у којем је мисао, пре би се рекло, стална замишљеност, а из те замишљености светионичара не буди ништа, чак ни његов посао (Sienkiewicz 1964: 363).

Сјенкјевич у овом одељку вешто комбинује реалистичко приповедање, „вајање“ јунака од малих појединости, с филозофским, често лирски обојеним рефлексијама немаркираног приповедача, овако сводећи битисање свог јунака на светионику:

У непрестаној самоћи и суочењу с околишем, необично једноставном а великом, почео је старац да губи осећај сопствене посебности, престајао је да постоји као личност и сливао се све више с оним што га је окруживало. Није о томе размишљао, осећао је само без јасног сазнања, али на концу му се чинило да су небо, вода, његова хрид, кула и златни пешчани спрудови, и напета једра, и галебови, плиме и осеке - некакво велико јединство и једна огромна тајанствена душа; он пак сам урања у то тајанство и осећа ту душу која живи и умирује се. Утонуо је, уљуљкао се, занео - и у тој ограничености властитог, засебног битка, у томе полубдењу-полусну нашао тако велико спокојство да беше готово налик на полусмрт (Sienkiewicz 1964: 367). 4

4 У светлу сучељавања концепата сећања и заборава у Светионичару, па и њихове вредносне амбиваленције, занимљиву интерпретацију Сјенкјевичеве новеле даје савремени истраживач Гжегорж Мархвињски (Marchwiński 2017: 201-203). 
Ништа, дакле, не најављује дисбаланс, испадање из равнотеже, мућење овог великог пантеистичког мира, ове земаљске нирване...5 Ипак, следи драматичан прелом.

У једном од кључних текстова о Сјенкјевичевом делу Светионичар прочитан изнова“ (Latarnik na nowo odczytany, 1967) Казимјеж Вика приповедање у овом одељку новеле, пре прелома, означава као њен универзални слој, као врсну студију старости, разумљиву и узбудљиву за читаоце свих поднебља (Wyka 1967: 79-81). Пре Вике пажња се, наиме, обраћала искључиво на оно што у Сјенкјевичевом тексту овај научник означава као „пољску идеолошку носивост“, дакле, на онај специфично, партикуларно пољски слој који једва да може имати одјека код читаоца изван пољског културно-језичког контекста. А тај идејни, па и идеолошки набој новела, истини за вољу, добија тек - после прелома.

Трећи и завршни одељак Сјенкјевичевог Светионичара почиње речима: „Али стигло је буђење“ (Sienkiewicz 1964: 367).

Сасвим неочекивано, с намирницама и водом, Скавињском стиже пакет с књигама, насловљен на његово име. Књиге, а то поуздано знамо заправо само за ону једну коју је узео у руке, биле су на пољском језику. У овом чуду које је задесило несрећног пустињака - читаоцу помаже да се снађе приповедач: „У првом тренутку заборавио је очевидно да је још на почетку своје светионичарске каријере прочитао једном у Хералду, узајмљеном од конзула, како се у Њујорку оснива пољско друштво, те да је друштву послао половину своје месечне плате, с којом, уосталом, на кули и није знао шта би“" (Sienkiewicz 1964: 367). Чудо је, дакле, било сасвим реално: друштво чије је оснивање помогао узвратило му је пошиљком... Но, и поред тога:

Пољске књиге у Аспинволу, на његовој кули, у његовој осами била је то за њега некаква сасвим изузетна ствар, некакав дах давних времена, чудо некакво. Сад му се учинило, као оним морепловцима у ноћи, да га је нешто позвало по имену гласом јако вољеним а готово заборављеним. Преседео је часак затворених очију и био готово сигуран да ће кад их отвори сан ишчезнути. Не! Распорени пакет лежао је недвосмислено пред њим, осветљен сјајем поподневног сунца, а на њему већ отворена књига (Sienkiewicz 1964: 367-368).

5 Тумачећи овај одељак новеле студентима, Мирослав Топић указивао је на јасну паралелу Сјенкјевичевог текста са „Сангинерским светиоником“ из Додеових Писама из моје ветрењаче и проналазио чак поједине интертекстуалне маркере. 
Од „већ отворене књиге“ почиње велика магија читања, симфонија саткана од детаља суптропског пејзажа, реминисценција и - лектире. Није Сјенкјевич нигде споменуо ни име аутора те отворене књиге, нити наслов дела - пољском читаоцу то није требало, јер сваки писмен Пољак без имало тешкоћа, на први поглед, могао је да одгонетне, а може то и дан-данас: Адам Мицкјевич, Пан Тадеуш. Кључни моменат навешћемо у ширем одломку:

Бистро небо није мутио ни облачак, неколико галебова мирно је пловило у плаветнилу. Океан је био уљуљкан. Приобални таласи једва да су тихо мрморили изливајући се благо на песак. У даљини су се осмехивале куће Аспинвола и чудесне групе палми. Доиста беше некако свечано а тихо и озбиљно. Наједаред усред тога мира природе пронесе се дрхтави глас старца који је читао наглас да би самога себе боље разумео: 6

Литво, о родна грудо, ти си ми ко здравље!

Каква је цена твоја, онај тек разуме

Ко изгуби те. Данас чар лепоте твоје

Видим и описујем, јер чезнем за тобом. 7

Скавињском понестаде гласа. Слова почеше да му скачу у очи; у грудима му се нешто откиде и крену попут вала од срца све више и више гушећи глас, стишћући за грло... Још један трен, па се обузда и стаде читати даље:

Дјево света што зрачну браниш Ченстохову

И сјаш у Острој Брами! Ти што градски бедем

У Новогрутку чуваш с народом му верним!

Ко мени што маленом здравље врати чудом

(Кад мати, плачућ, твојој предаде ме бризи,

Те обамрле тада подигох ја капке,

И одмах могох пешке прагу Твога храма

За враћен живот доћи да захвалим Богу),

Тако нас чудом врати крилу Отаџбине... (Sienkiewicz 1964: 368-369).

Сунце је залазило, Скавињски је читао и читао мешајући свим чулима доживљај морског пејзажа Панаме с пејзажима континенталне Литве из Пана Тадеуша и својим искуствима из младости. Пољски романтичар био је свестан да се с чудесним повратком у Отаџбину мора још чекати, те у стиховима 14-15

6 Скавињски чини исто што и онај светионичар на Сангинерском светионику који наглас чита Плаутове комедије - да би остао будан...

7 Одломци из Пана Тадеуша дају се према својевремено начињеном пилотпреводу првих педесетак стихова у неримованом пољском тринаестерцу, аутор П. Б. 
првог певања моли за чудо преношења душе у родни крај, одакле почиње прелом и у његовом казивању:

А засад носи моју душу чежње пуну

На она брда шумска, ливаде зелене... (Sienkiewicz 1964: 368-369).

Ово је уједно и „окидач“ за Скавињскога. Пошто је тек сумрак затро слова, старац је наслонио главу на стену и затворио очи... „А онда је 'Она што зрачну брани Ченстохову' узела његову душу и однела 'на поља што их слика жито разнобојно'“ (Sienkiewicz 1964: 369). Засад само сигнализирамо чињеницу да је последњи наведени стих („на поља што их слика жито разнобојно“), 17. по реду у Мицкјевичевом спеву, уједно и последњи који се дословно цитира у Сјенкјевичевој новели. 8

Следи преплитање сна и јаве, домаћег, родног, са суптропским, један разуђени калдероновски мотив изложен у узвишеном, свечаном тону, нпр.:

Сати се лењо развлаче, напослетку се светла гасе; сад је, докле год поглед сеже, магла, магла непрозирна: пара се очигледно диже с ливада и обавија свет цели беличастом копреном. Рекао би човек: прави океан. Али то су ливаде: сваког часа огласиће се прдавац у тмини и букавци загудети у трсци. Ноћ је мирна и хладна, права пољска ноћ! (Sienkiewicz 1964: 370)

Расплет је јасан: светионик није упаљен, брод се насукао и Скавињски губи свој земаљски рај. Пред њим се отвара перспектива нових потуцања.

Описујући нешто раније буру светионичаревих носталгичних осећања, наратор вели: „Он се једноставно тим великим плачем извињавао оној вољеној, далекој због тога што је већ толико остарио, што се толико саживео с усамљеном хриди и толико занео да је у њему и чежња почела да се затире“ (Sienkiewicz 1964: 369). Вољена, далека - отаџбина. А у завршници - видно усукан и згрбљен после губитка посла - „само је имао сјај у очима“, јер је „за нове животне путеве имао на грудима и своју књигу коју је с времена на време притискао руком као да се боји да и она не нестане...“ (Sienkiewicz 1964: 371). У питању је и даље отаџбина, а кроз вербалну игру с јасном асоцијацијом на патриотску песму „Мазурка Домбровског“ („Mazurek Dąbrowskiego”, данас пољску државну химну) износи се највиша оцена која би се могла дати

8 Овамо не убрајамо полуцитат из 5. стиха Пана Тадеуша („Она што зрачну брани Ченстохову“), који служи као стилски потенцирана перифрастична метонимија за Богородицу. 
Пану Тадеушу - он је есенција, својеврстан преносиви реликвијар отаџбине за све оне који су од ње далеко...

Од појаве књиге на острву у новели Светионичар отвара се онај доминантни семантички слој који се у свести пољског читаоца, правог адресата приповедања, денотира као - патриотизам.

Савремени аутор, методичар науке о књижевности Јануш Валигура, врло инвентивно, али у првом реду критички ишчитава Светионичара, прави „модел пољског патриотизма“ и покушава да га суочи с приликама у савременом свету. Судбину јунака новеле, као и претходници, посматра у два плана - егзистенцијалном (универзалном) и партикуларном (пољском), при чему примећује да се, захваљујући узвишеним стилским средствима, тај романтичарски модел пољског патриотизма, односно пољског духа, уздиже на пиједестал светости (sacrum). При томе „наратор-идеолог односи превагу над наратором-психологом и мислиоцем“ (Waligóra 2020: 158), а резултат је својеврсно супротстављање Пољака свету. Наравно, аутор не сматра да је у савременом мултикултуралном свету овакав модел пожељан, напротив.

Не спорећи да у доживљају савременог читаоца Сјенкјевичева новела може оптерећивати својим високим стилским регистром, па можда и својом патетиком, сигурно је једно: последњих деценија XIX и првих XX века, захваљујући поред осталог и Светионичару, Пан Тадеуш постао је централно дело пољског романтизма, сублимат „пољскости“, имаголошки кладенац за концепт „дома“ и „домаћег“, „свог“ и „својског“, а патриотски набој Сјенкјевичеве новеле - енергетски подстицај поколењу које је Пољску водило ка поновном стицању независности 1918.

\section{2.}

Осврнућемо се на генезу лика Скавињског у светлости ауторске напомене уз наслов Светионичара: „Ова прича заснована је на истинитом догађају о којем је у своје време писао Ј. Хорајн у једноме од својих писама из Америке“ (Sienkiewicz 1964: 356). Нећемо у томе, разуме се, бити никако ни први, а ни последњи. Данас се елементи те генезе сматрају општепознатим чињеничким творивом метатекста Сјенкјевичеве новеле, па ипак остаје простора да се још понешто дода.

Још је књижевни историчар Јулијуш Клајнер у првој половини прошлога века приметио следеће: 
Ремек-дело Сјенкјевичеве композиције, главна сцена Светионичара, има мало равних у светској књижевности. Искористио је овде стваралац богатство асоцијација с ликом устаника и емигранта, са сликом океана и појмом Америке, најпосле с Паном Тадеушем; свог јунака приказао је у тренутку у којем се у сноп скупља сав садржај његовог болног и племенитог живота; дао је Пану Тадеушу идеалног читаоца, а Скавињскоме у руке ставио идеалан, као за њега писан спев; ту једноставну, па ипак изузетну сцену учинио је преломном тачком судбине једнако изузетне колико и типичне - и нимало се не удаљавајући од апсолутне стварности, уздигао је на висину симбола националне трагедије (Kleiner 1925: 160).

Идеални читалац, идеално дело, симбол - све ово имплицира свакако висок степен стилизације стварних предложака, поготово узме ли се у обзир „истинити догађај“.

Први је прегао да тај „истинити догађај“ истражи - идући трагом књижевника и публицисте Јулијана Хорајна (Julian Horain, 1821-1883) - приређивач Сјенкјевичевих целокупних дела Јулијан Кшижановски. Он је најпре у чланку „Сјенкјевичев Светионичар“ („Sienkiewiczowski Latarnik“, 1950), потом у књизи Хенрик Сјенкјевич. Календар живота и стваралаштва (Henryk Sienkiewicz. Kalendarz życia i twórczości, 1956), а на концу у својим књижевноисторијским огледима о Сјенкјевичу Из проучавања Сјенкјевича (Pokłosie Sienkiewiczowskie, 1973) први сучелио уметнички уобличеног јунака новеле с његовим прототипом. Први је и поново публиковао део Хорајновог писма Газети пољској (Gazeta Polska, 1877, бр. 32) који се односи на тај „истинити догађај“.

Хорајнов текст, тачније, део који нас занима, почиње речима: „Њујоршка штампа јавила је за смрт нашег земљака Сјелаве [Siellawa], некад становника витебске губерније“. Хорајн је лично познавао покојника, па је одлучио да подели са читаоцима нека сазнања о њему. Индикативно је да му није знао крштено име, што и наглашава. Био је, према Хорајновим речима, високо образован, честит и племенит човек, али патио је од - маније гоњења: „свуда где год би боравио чинило му се да га шпијунира, прати и прогања једна од европских влада“ (мисли се, наравно, на царску Русију, али се то због цензуре ретушира). Због те маније Сјелава се нигде није дуго задржавао, па је напустио Европу, како Хорајн цени, око 1848. и боравио на Рту добре наде, Мадагаскару, у Аустралији, Јужној, Средњој и напослетку Северној Америци. Више пута је причао аутору репортаже како је најсрећнији период његовог живота било 26 месеци проведених на светионику 
десет миља од луке Аспинвол у Панами. Једаред му је, заједно с намирницама, стигао пакет с пољским новинама и књигама - „и то га је изагнало из усамљеничког раја у којем је живео најсрећније, без Еве и змије, како је сам говорио“. Међу књигама био је роман Зигмунта Качковског Мурделио (Murdelio, 1853). Зачитао се Сјелава и - заборавио да упали светионик, због чега је истеран с посла. Сматрао је да је и та пошиљка била резултат интриге исте оне „европске владе“, па је омрзнуо књиге и читање, те све које је сумњичио да му раде о глави називао именом Мурделио. Касније је служио по апотекама у Њујорку, а пошто је патио од несанице, користио је морфијум којим се наводно отровао... (уп. Krzyżanowski 1973: 187-188) ${ }^{9}$

Као допуну ове Хорајнове репортаже Кшижановски наводи кратак чланак из Њујорк тајмса од 23. новембра 1876. „Смрт апотекарског службеника“ (“A Drug Klerk’s Death”). Из тог чланка сазнајемо сувопарне али вредне појединости: Сјелава је радио у апотеци и становао у соби иза локала, где је и пронађен мртав. Обдукцијом је утврђено тровање цијановодоничном („пруском“) киселином, премда ништа није указивало на самоубиство, што се документује непослатим Сјелавиним писмом, нађеним у његовом џепу, из којег се види да планира повратак у домовину. Имао је 38 година, високо образовање и говорио неколико језика. У Америку је стигао „пре петнаестак година“ (дакле, око 1865) и 1872. од њујоршке фармацеутске коморе добио лиценцу апотекарског помоћника. Споменимо на крају да је др Вилсон, власник апотеке, обавестио истражног судију да је Сјелава био зависник-морфиниста (уп. Krzyżanowski 1973: 188-189). ${ }^{10}$

Кшижановски не тврди да је чланак из Њујорк тајмса Хорајнов извор, већ га наводи због прегршти аутентичних података. Па ипак, једно је сигурно: Хорајн, када спомиње њујоршку штампу, није имао на уму овај чланак, јер га сасвим очигледно није читао. Апотекарски помоћник, Пољак, рођен око 1838 (у тренутку смрти 1876. имао је 38 година), именом и презименом био је Мјечислав (sic!) Сјелава.

Треба нагласити да се Хорајн заправо нигде и не изјашњава о Сјелавиној старости, а једини временски маркер у његовом тексту јесте нагађање да је Европу напустио „чини се“ 1848 .

Безмало годину дана после Хорајна, Сјенкјевич је у једној својој репортажи за Курјер цођени (Kurier Codzienny $=$ Дневни

9 Вид. графички прилог 1 на крају рада.

10 Вид. графички прилог 2 на крају рада. 
курир), писаној у другој половини децембра 1877, поновио причу о несрећном Сјелави, али је и мало „досолио“, а мало више „одсејао“. ${ }^{11}$ Почиње податком да је недавно „умро стари [курзив наш] човек презименом Сјелава“, „веома несрећан“. У продужетку се нижу елементи за будућу новелу: „Где све није био, којим све путевима није прошао, тешко би било и набројати“, а затим, мимо Хорајновог текста, „лутао је међу Индијанцима; насукавао се на све обале пет континената, час зарађивао неку цркавицу, час губио... речју: био је то лист ношен буром“. Ипак, имао је две срећне године у животу - године службе на светионику код Аспинвола. „У шест сати увече палио је фар, у шест ујутру гасио - а у преостало време ловио рибу, понекад се загледао у једра која би се појавила у плаветној даљини, удубљивао се у ту даљину... маштао и сањао“ (Sienkiewicz 1950: 218). Као и у новели, изненада је дошао крај његовој срећи. И узрок је томе - Мурделио Зигмунта Качковског. „Старац је читао, читао не само очима, већ душом и срцем“ и заборавио да упали фар, те тако изгубио посао. Карактеристична је завршница: „Сјелава је стигао потом у Њујорк и тамо се отровао - наводно због беде. Поред њега нађен је Мурделио [sic!]“ (Sienkiewicz 1950: 218). Као што се можемо уверити, нема морфијума, већ се подразумева резултат употребе некаквог неодређеног отрова. Одлучио се Сјенкјевич за самоубиство, иако га је, знамо, истрага искључила - згодније је, уметнички заокруженије. Ништа од занимања апотекара. Ништа од Хорајнове приче о томе како је омрзнуо књиге и читање, нити о имену Мурделио које је надевао сваком непријатељу, напротив - књигу која је узрок његове несреће наставио је да обожава! Како било, прича из Курјера цјођеног готово да је сасвим уобличена скица за потоњу Сјенкјевичеву новелу. Процес стваралачке прераде стварности, дакле, већ се тада увелико захуктавао...

Књижевним ликом, Скавињским, у светлу конфронтације са стварносним прототипом, најтемељитије се досад бавио Казимјеж Вика у већ споменутом чланку. Вика издваја два слоја - ратничку биографију под оружјем и биографију луталице без оружја. При томе настоји да успостави колико-толико веродостојну хронологију у биографији имагинарног јунака, као и временски след описаних збивања. Пођимо редом.

11 Ово је примећено у досадашњој литератури, али рекло би се да није посебно вредновано. Вид. Waligóra 2020: 160 и литературу на коју се позива у напомени 8. 
Када Скавињски обавља разговор с конзулом, сам излаже своју ратну биографију.

Стари човек извади из недара избледели комад свиле налик на део старог барјака. Разви га и рече:

- Ово су сведочанства. Овај крст добио сам тридесете године. Овај други је шпански из карлистичког рата; трећи је француска легија; четврти сам добио у Мађарској. После сам се борио у Cједињеним Државама против Јужњака, али тамо не деле крстове, па ево папира (Sienkiewicz 1964: 357-358).

Вика из тога закључује да је Скавињски учесник пољског Новембарског устанка (1830-1831), емигрант после његовог слома. Када касније у тексту новеле наратор констатује, „ево, још мало па се навршавало четрдесет година откад није видео домовину“ (Sienkiewicz 1964: 369), то значи да се „актуелна“ радња Cветионичара збивала око или мало пре 1870. године, а да је он сам рођен око 1810, те да је, дакле, вршњак пољских романтичара (уп. Wyka 1967: 72). А даљи ратнички пут Скавињског је, према Вики, овакав: карлистички рат у Шпанији (1833-1837 12 , француско освајање Алжира које је трајало од 1830 (Вика, наиме, не види где би другде могао заслужити француски орден Легије части), затим Мађарска револуција (1848-1849) и - амерички грађански рат (1861-1865) (уп. Wyka 1967: 72).

Као представник поколења устаника-емиграната, Скавињски се, како приповедач наглашава, и раније сретао с именом аутора „своје“ књиге, Мицкјевичем, а то Вику упућује на закључак да је, као и читава емиграција, био упознат с његовим месијанистичким списом Књиге пољског народа и пољског ходочашћа (Księgi narodu polskiego i pielgrzymstwa polskiego, 1832). И Скавињски је, као сви емигранти после 1831, живео у ишчекивању великог европског сукоба народа̂ из којег ће се родити независна Пољска. Отуд још једно значење напред већ навођених речи:

...увек је био пун вере и није губио наду да ће све још изићи на добро. Зими би увек живнуо и предсказивао некакве велике догађаје. Чекао их је нестрпљиво и од саме мисли на њих преживљавао читава лета... (Sienkiewicz 1964: 361)

Нада и оптимизам свему упркос, којима се завршава Сјенкјевичева новела, наводи Вику на закључак да се радња новеле завршава пре 1870, тј. пре Битке код Седана, пада Наполеона III и Другог царства. Ти су догађаји, наиме, ставили крст на овакве наде пољских емиграната-романтичара (уп. Wyka 1967: 73).

12 Подаци из других извора казују да се први карлистички рат водио до 1840. 
Узгред споменимо да Вика примећује како је од Сјелаве, оног Хорајновог, Скавињски „наследио“, у траговима, манију гоњења, премда то у новели изгледа битно другачије (уп. Wyka 1967: 76):

Чинило му се [...] да га прогоне све четири стихије. Они који су га знали, говорили су да нема среће и тиме објашњавали све. Он је сам напослетку мало постао манијак. Веровао је да га некаква снажна и осветољубива рука прогони свуда, по свим копнима и водама. Није, међутим, волео о томе да прича; само би понекад, кад су га питали чија би то могла бити рука, тајанствено показивао звезду северњачу и одговарао да то долази отуд... (Sienkiewicz 1964: 360).

Долази, дакле, са севера, евидентно из једне царевине...

У вртлогу визија који је јунаку покренула лектира Пана Taдеуша као врло значајан податак Вика издваја овај: „Не види родну кућу, јер ју је затро рат, не види оца ни мајку, јер су умрли док је био дете; у свему осталом село - као да га је јуче напустио“ (Sienkiewicz 1964: 370). Из изреченога, наиме, изводи закључак да Скавињски није био коленовић, шљахтић: „Отуда је, као човеку који се потуца трбухом за крухом, Сјенкјевич могао да му да̂ све особине пољског сељака-емигранта: радин, честит, стрпљив, мрав људски којег ниједан камен није кадар да згњечи“ (Wyka 1967: 77).

„Друга“ биографија Скавињског, она без оружја у руци, смештена је између ових драматичних историјских догађаја и богата је амплификација Хорајнове реченице о географији Сјелавиних лутања (уп. Wyka 1967: 76): био је, у најкраћем, копач злата у Аустралији, трагач за дијамантима у Африци, државни ловочувар у Источној Индији; у Калифорнији је основао фарму, али га је упропастила суша; окушао се у трговини с дивљим племенима у унутрашњости Бразила, али преврнуо му се сплав на Амазону, па је недељама лутао прашумом; основао ковачку радњу у Хелени у Арканзасу, али је изгорела у великом пожару града; у Стеновитим планинама заробили га Индијанци; био је морнар на бродској линији између Баије и Бордоа, затим харпунар на китоловцу, и оба су брода потонула; имао је фабрику цигара у Хавани, али покрао га је ортак - све док није завршио на светионику... (уп.: Sienkiewicz 1964: 360; Wyka 1967: 77). У овом слоју животописа Скавињски је представљен као Сизиф - био је упоран и радан као мрав: „Гурнут низбрдо сто пута, мирно је започињао свој успон стотину и први пут“" (Sienkiewicz 1964: 361).

Па ипак, да ли у једну индивидуалну биографију може стати све ово? Све то војевање с оружјем у руци и све то егзистенцијално војевање без оружја? Наравно да не. Сјенкјевич је свесно гра- 
дио симболичког јунака, таквог да у себи једноме у сноп повеже све судбине пољских емиграната - политичких и економских и сву њихову трагедију. За лик Скавињског не може се рећи да је „реалистички“, па чак ни „веродостојан“ јунак, он је заправо симболички колективни јунак (уп. Wyka 1967: 76-77). Сјенкјевич је у њему начинио, дакле, сублимацију Пољака-емигранта припремајући га све време - за Пана Тадеуша. У тој сублимацији било је места чак и за историјског Сјелаву... ${ }^{13}$

3 .

Роман Мурделио Зигмунта Качковског био је половином XIX века, недуго уосталом, веома популаран. У питању је успела стилизација „племићког казивања“ (gawęda szlachecka) с радњом из XVIII века, после прве поделе Пољске (1772), својеврсна глорификација шљахте, њеног живота и обичаја и племићке републике из доба декаденције. Јунак из наслова Мурделио ${ }^{14}$, један је од првих демонских јунака у пољској прози, те, узгред, нимало не чуди што историјски Сјелава ово име користи као обичан апелатив. Радња романа интригантна је, љубавни заплети веома добри, артикулација сасвим „пољска“, традиционалистичка, прилично носталгична, па је било и више него разумљиво да се читалац онога доба могао удубити у његову лектиру и заборавити на светионик... Међутим, за Сјенкјевичеву замисао Мурделио је био потпуно неупотребљив. Супституцију Мурделио - Пан Тадеуш не доводи у питање нико од оних који су се бавили овом темом, почевши од Кшижановског ${ }^{15}$; сви је они, наиме, доживљавају као аксиоматску нужност, јер без Пана Тадеуша не би било тако ефектног „сокола у новели“, нити би се могао изградити тако дубок патриотски и мартиролошки план њеног значења. Примера ради, велики зналац Сјенкјевичевог књижевног наслеђа Тадеуш Бујњицки о томе пресуђује по кратком поступку: „Замена Мур-

13 Савремена ауторка понудила је за ову рефлексију врло индикативно размишљање о Светионичару и Скавињском као својеврсној антиципацији пишчеве властите животне завршнице. Сјенкјевич је, наиме, од 1914. па до смрти 1916. живео у Швајцарској - као емигрант (уп. Adamek-Świechowska 2016: 126-128).

14 То је назив породичног грба под којим насловни јунак крије свој идентитет.

15 „Случај старог Сјелаве, трансформисан у складу са законима фикције, благодарећи том захвату, уопштен је и ојачан, сиров животни, историјски материјал претворио се у изврстан песнички материјал“, вели Кшижановски у својој књизи Henryk Sienkiewicz. Kalendarz życia i twórczości (1956) - цит. према Wyka 1967: 79. 
делија Паном Тадеушем покреће богат ланац асоцијација, изазван тиме што дело Качковског заостаје за великим дѐлом пољске емиграције“ (Bujnicki 1998: 7).

О функцији Мицкјевичевог спева на плану симболике и семантике Сјенкјевичеве новеле било је већ речи, те то питање, држимо, овде није потребно посебно продубљивати.

На плану фабуле Светионичара Пан Тадеуш има, готово да би се могло и тако рећи, деструктиван карактер. Од тренутка појављивања „отворене књиге“ у новели се све руши: почевши од непрестано потенциране силазне криве животописа главнога јунака и његовог земаљског раја, па, у крајњој линији, до кохеренције самог приповедања. Јоана Вароњска у том смислу износи веома важно запажање, а то је да Сјенкјевич, као аутор новеле, и câм чита Мицкјевича (уп. Warońska 2003: 32), додали бисмо као узбуђени читалац.

Како, дакле, функционише текст Пана Тадеуша у Светионичару?

Као што је већ било речи у претходном излагању, читаоцу новеле јасно је предочено шта њен јунак као читалац чита тако што су цитирани реперни стихови, они са самога почетка. Да прецизирамо: цитирају се, графички издвојени у посебне одељке, стихови 1-15; у наводницима, у тексту, цитира се стих 17. Изостављен је само 16. стих где се додатно дефинишу ливаде зелене („широко над Њеменом плавим разастрте“), уосталом без неког видљивог разлога. Дакле, у новели Светионичар наведено је у целини укупно 16 стихова с почетка прве књиге Пана Тадеуша.

Па ипак, на томе се не завршава присуство овога спева у тексту Светионичара. Мирослав Топић, и иначе необично пажљив читалац, у одељку посвећеном визији Скавињског указивао је на кључне речи и појмове као елементе синтезе његових пробуђених успомена и песничких слика из Пана Тадеуша.

Тако у опису села, које као да је Скавињски „јуче напустио“, наилазимо на следећи низ: „młyn, dwa stawy, podane ku sobie i brzmiące całą noc chórami żab” („воденица, два јаза окренута један наспрам другоме којима читаву ноћ одјекују хорови жаба“, Sienkiewicz 1964: 370). Овде је у питању свођење, симплификација или чак извлачење кључних речи и фраза из богато разрађених песничких слика у Пану Тадеушу. 
Погледајмо најпре одакле потичу два јаза и хорови жаба:

Odezwały się chórem podwójnym dwa stawy, Jako zaklęte w górach kaukaskich jeziora, Milczące przez dzień cały, grające $\mathrm{z}$ wieczora (VIII, $38-40^{16}$ ).
Јавише се удвојеним хором два јаза Као зачарана језера кавкаских планина, По ваздан тиха, а распевана пред вече. ${ }^{17}$

Још нема хорова, али мотив двају јазова пуних жаба среће се у Мицкјевичевом спеву на више места, па ће се наћи готово одмах у наставку:

W obu stawach piały żab niezliczone hordy, У оба јаза певале су жаба хорде небројене, Oba chóry zgodzone w dwa wielkie akordy Оба хора усклађена у два велика акорда. (VIII, 45-46).

Сложићемо се да синтагма хор жаба, која и на пољском звучи једнако необично као и на српском, у Сјенкјевичевој новели није могла бити пука случајност.

На другом месту у истој VIII књизи наилазимо и на мотив окретања јазова једног према другом:

Dwa stawy pochyliły ku sobie oblicza Jako para kochanków...(VIII, 587-588).
Два јаза нагоше један другоме лица Као заљубљени пар...

У Мицкјевичевој топографији - баш као што је то поновљено и у Светионичару - уз два јаза иде, неизоставно, и воденица: „Między stawami w rowie młyn ukryty siedzi” (VIII, 621) - „Између јазова у каналу седи воденица скривена“. Инверзијом мотива, речи и слика Сјенкјевич заправо камуфлира овај слој присуства Пана Тадеуша, позивајући читаоца на игру.

У напред већ навођеној Сјенкјевичевој реченици која следи за малочас наведеном (у цитату је курзив наш): „Ale to łaki: rychło czekać, jak derkacz ozwie się w ciemności i bąki zahuczą po trzcinach" („Али то су ливаде: сваког часа огласиће се прдавац у тмини и букавци загудети у трсци“, Sienkiewicz 1964: 370) сведоци смо, како је то истицао М. Топић који је ову појаву уочио, нечег још занимљивијег. Кључне речи доведене су у сазвучје (takil|baki), а заправо је то одјек Мицкјевичеве риме:

16 Пошто је реч о веома познатом делу које се појавило у мноштву ауторитативних издања, уз цитате наводимо римским бројем књигу (певање), а арапским стихове. Ми смо се користили издањем Mickiewicz 1998.

17 Овде дајемо филолошки превод одломака из Пана Тадеуша - П. Б. 
Już trzykroć wrzasnął derkacz, pierwszy skrzypak łąki, Już mu zdała wtórują z bagien basem bąki

(VIII, 33-34).
Већ трипут дрекну прдавац, први гудач ливаде, Већ га издалека из мочвара басом букавци прате.

Јављају се код Сјенкјевича, као што видимо, обе барске птице „незгодних“ српских назива из наведених стихова (derkacz, bąk), али у прозном казивању, без ритмизације која би указивала на филијацију из песничког текста, вешто је прокријумчарен римовни пар (łaki||baki) из стихова 33-34 VIII књиге Пана Тадеуша.

Нису насумице изабрани ови стихови из Мицкјевичевог спева. Они су део једног од трију „концерата“ - „концерта природе“ - из Пана Тадеуша, који у романтичарском спеву доприносе синестетском (у овом случају доминантно акустичном) доживљају родног пејзажа, стапању слике и звука, управо онога што се догађа у визији Скавињског...

Индикативно је да, бар колико је нама познато, пољски истраживачи нису посебно вредновали ову особеност текста Сјенкјевичеве новеле. Чак и тако дубоко аналитичан читалац као што је био Казимјеж Вика, који у свом прекретничком раду о Светионичару цитира одељак са скривеном римом (уп. Wyka 1967: 81), без коментара прелази преко ових редака. Није разлог томе, наравно, непажња, већ је Пан Тадеуш поколењима пољских читалаца, професионалаца и лаика, толико „у крви“ да све ове сигнале, гласове и слике, којима Сјенкјевич тако вешто оперише, доживљавају као „своје“, блиске и домаће, дакле - подразумеване.

А предочене чињенице, надамо се, јасно сведоче о томе да Пан Тадеуш у Светионичару не функционише само као стандардни феномен интертекстуалности, већ да је дубоко продро у само твориво Сјенкјевичевог текста, у њему се проширио - можда грубо звучи, али метастазирао - те да на више нивоа конституисања смисла постаје пуноправни „текст у тексту“. Он готово да тежи некаквом осамостаљивању, тежи да и са̂м постане - литерарни јунак...

\section{Извори}

Mickiewicz, A. (1998). Pan Tadeusz. Dzieła, IV. Warszawa: Czytelnik.

Sienkiewicz, H. (1950). List Litwosa. In Listy z podróży do Ameryki, II. Dzieła, XLII. Warszawa: PIW, 218-219.

Sienkiewicz, H. (1964). Latarnik. In Nowele, I. Warszawa: PIW, 356-371. 


\section{Лuтература}

Буњак, П. (1999). Преглед пољско-српских књижевних веза (до II светског рата). Београд: Славистичко друштво Србије. Исто: <http:// www.rastko.rs/knjizevnost/nauka_knjiz/pbunjak-veze_c.html>

*

Adamek-Świechowska, A. (2016). „Blaski Miltonowskiego utraconego raju”. Obraz przeszłości w pisarstwie Henryka Sienkiewicza. Acta Universitatis Lodziensis, Folia Linguistica, 50, 117-132.

Bujnicki, T. (1998). Henryk Sienkiewicz „Latarnik”. In Grzeszczuk, S. (red). Lektury polonistyczne. Pozytywizm - Młoda Polska, I. Krakow: Universitas.

Kleiner, J. (1925). „Artyzm Sienkiewicza”. In Sztychy. Lwów-WarszawaKraków: Ossolineum, 157-173.

Krzyżanowski, J. (1973). O „Latarniku”. In Pokłosie Sienkiewiczowskie: szkice literackie. Warszawa: PIW, 186-194.

Marchwiński, G. (2017). Między pamiętaniem a zapominaniem. Społeczne aspekty asymilacji w opowiadaniach migracyjnych Henryka Sienkiewicza. In Dąbrowicz, E., Larenta, B., Domurad, M. (red). Świadectwa pamięci. $W$ kręgu źródel i dyskursów (od XIX wieku do dzisiaj). Białystok: Uniwersytet w Białymstoku, 187-206.

Waligóra, J. (2020). Izolacje i dewiacje... O Sienkiewiczu, narodzie i (turbo) patriotyzmie. Polonistyka. Innowacje, 11.

Warońska, J. (2003). Panem Tadeuszem odczytywanie Latarnika. Prace Naukowe Wyższej Szkoły Pedagogicznej w Częstochowie. Seria: Filologia Polska. Historia i Teoria Literatury, IX, 31-37.

Wyka, K. (1967). „Latarnik” na nowo odczytany. In: Olszewicz, B. (red). Księga pamiątkowa w 15o-lecie Zakładu Narodowego im. Ossolińskich. Wrocław: Ossolineum, 71-82.

\section{Препоручена литература}

Bujnicki T., Bursztyńska H. (red) (1984). „Latarnik” Henryka Sienkiewicza. Interpretacje (skrypt dla studentów filologii polskiej). Katowice: Uniwersytet Śląski. 
Miroslav Topić

Petar Ž. Bunjak

University of Belgrade, Faculty of Philology

\section{REVISITING HENRYK SIENKIEWICZ'S THE LIGHTHOUSE KEEPER}

\section{- Summary -}

The article provides a wide overview of previous research on Henryk Sienkiewicz's novella The Lighthouse Keeper (1881). Special attention is paid to the following two topics: the genesis of the main character (its relation to the historical prototype) and the role that Adam Mickiewicz's poem Master Thaddeus plays in the novella. The authors also offer some results of their own research on that matter, specifically on the multiple function of Mickiewicz's poem as "text-in-text" within The Lighthouse Keeper.

Keywords: Henryk Sienkiewicz, The Lighthouse Keeper (Latarnik), genesis, characterology, Adam Mickiewicz, Master Thaddeus (Pan Tadeusz), "text-in-text". 


\section{ПРИЛОЗИ}

\section{Прилог 1}

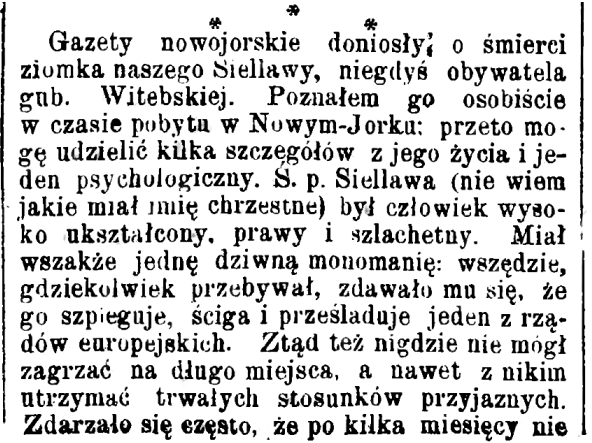

pokazywal sie żadnemu z ziomków, i zwykle nie wiedziano gdzie mieszka. Gnany myślą, ż go ścigają í prześladują, po opuszczenia Europy (zdaje sit w roku 1848), zwiedzil Przylądek Dobrei Nadziei, Madagaskar, Australię. Amerykę Poludniową. Srodkowq i nareszcie Stany Zjednoczune.

Powiadal mi nielaz, ze najszczęśliwsze chwile swojego życia nważa tę parę lat, które przebyl na międzymorza Panama, spelniạiq̨e obowiązek strażnika latarni morskiej, pized portem Colon-A spinaall. Obowiz̨kiem jego było, o kaædej szóstej godzinie, zapalać lub gasić latarnię. Mieszkal o 10 mil od brzegu, sam jeden, wśród morza, na samotnej skale, której przez 26 miesięcy nie opuszczal. Co dwa tygodnie przy wo\%̆ono mu \%y wność. niekiedy zywe ptastwo lub barana (gdyz w tym klimacio mięso świeże pót dnia nie da się przechować). Raz mu pr'zyslano pake 7 gazetami i ksiazkami polskiemi, - i to go wygnało z samotnego raju, to którym źl najszczéśliušzy bez Eroy i weża, jak się sam wyrazal. W liczbie praysłanych ksiuzzek, była powieść Zygmunta Kaczkowskiego "Murdelio." Otóż, w pewien mglisty dzien. Siellawatak się zaczytal przy lampie owej powieści, te wiecznem praxem zapomn ał zapalić lampę latarnianą. 'To zmyliło z drogi jakiś okręt, i o malo nie stalo się powodem rozbicia. Zaskal'zono strużnika, i Siellawa stracil miejsce. Odtąd znienuwidzil ksiązki; is każdego, którego podejrzywal o złe względem siebie zamialy, nazywal "Murdelio." Przysianie zas kstążek przypisywał intrydze.... W Nowym Jorku pracowal po aptekach. Cierpiac bezsennośś, ażywał morfiny, czy innego jakie. goś niebezpiocznego lokalæxtwa, i tem się po.

dobno otruł. Dopiero : w kilks dni pójego śmierci, ziomkowie dowiedzieli się o tem i pośpieszyli pochować.

Gazeta Polska, 1877, 32, 2. 


\section{Прилог 2}

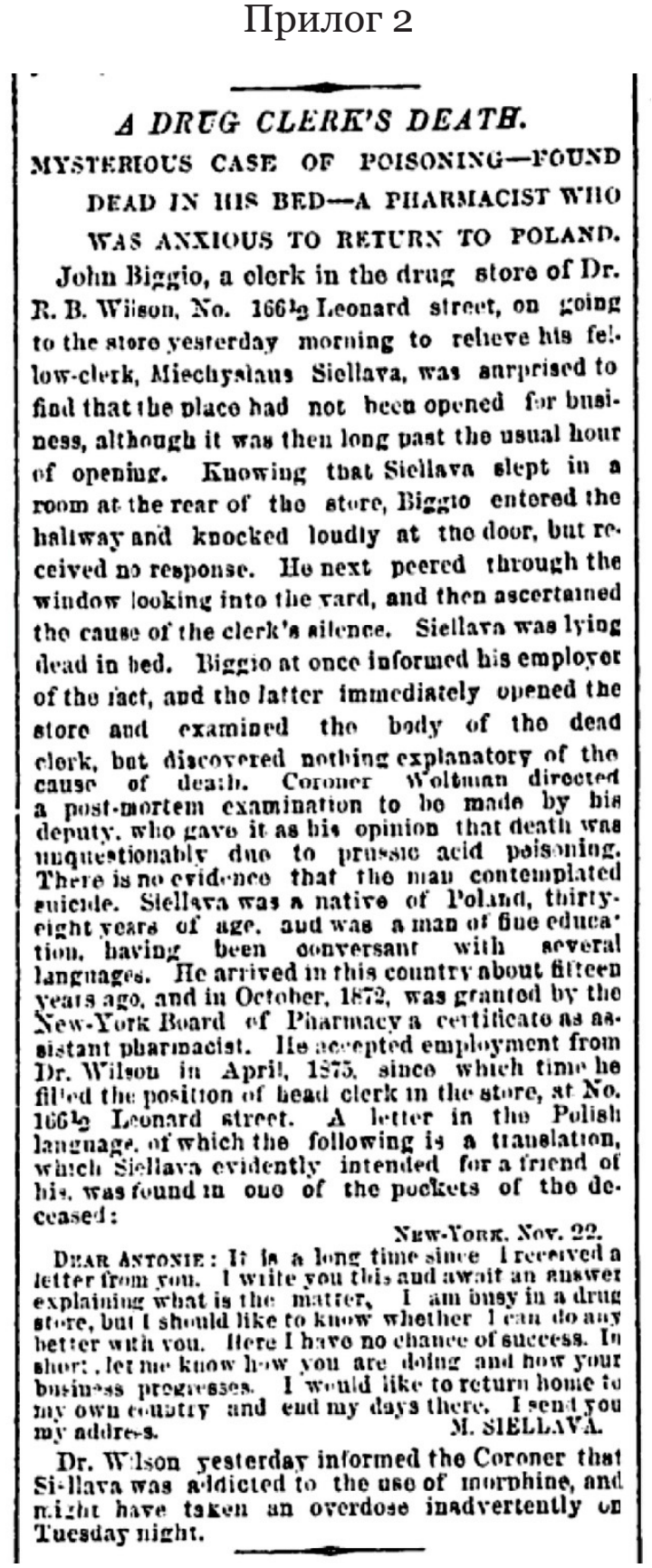

The New York Times, 1876, Nov. 23, 8.

(извор: TimesMachine_ November 23, 1876 - NYTimes.com) 